\title{
Women and Men Facing Lexical Innovation ${ }^{1}$
}

\section{Mujeres y hombres ante la innovación léxica}

Paola Cañete González²

Citation/ Para citar este Artículo: Cañete-González, P. (2017) Women and Men Facing Lexical Innovation. Colomb. Appl. Linguist. J., 20(1), pp. 219-233.

Received: 01-Aug-2016 / Accepted: 23-May-2017

DOI: http://dx.doi.org/10.14483/calj.v20n1.10627

\begin{abstract}
Over the last few decades, the gender variable has been investigated in terms of linguistic variation. A number of studies (mainly phonological in nature) have been carried out which have generated preliminary conclusions such as women are more conservative and use more standard forms of language than men or that men are more innovative than women (Chambers, 2009; Labov, 1994). Generally, we are aware that new words are created every day which is indicative of the dynamism of languages and the changes taking place in a given society. The study of new lexical entities, called neologisms, allows us to understand how language speakers adapt to social changes. The two issues mentioned above are our main motivation to conduct this investigation which will be based on a linguistic approach with a focus on neology. Hence, this paper focuses on Spanish neological units produced by women and men as found in contemporary newspaper articles and blogs through a qualitative analysis of neologisms used by women and men as well as a qualitative analysis of the formation of these neologisms. Finally, we present a comparison between the results obtained in both types of text.
\end{abstract}

Keywords: blogs, gender, lexical innovation, neologism, newspaper articles

\section{Resumen}

Desde el punto de vista de la variación lingüística se ha estudiado la variable género desde hace ya varias décadas; se han hecho estudios principalmente fonológicos y se ha llegado a conclusiones como las mujeres son más conservadoras y usan formas más estándar que los hombres o los hombres son más innovadores que las mujeres (Labov, 1994; Chambers, 2009). Por otra parte, sabemos que cada día surgen nuevas palabras en la lengua que dan cuenta de la vitalidad de ésta y de los cambios que ocurren en la sociedad, y a través de estas unidades llamadas neologismos podemos comprender mejor cómo los hablantes se adaptan a estos cambios. De estos dos aspectos surge el interés por realizar esta investigación cuyo objetivo es analizar, con un enfoque lingüístico desde el área de la neología, el impacto de la variable género en artículos y blogs de tres periódicos españoles a través de un análisis cuantitativo sobre la cantidad de neologismos utilizados por mujeres y hombres, un análisis cualitativo sobre el tipo de formación de estos neologismos, y una comparación de los resultados obtenidos en ambos tipos de texto.

Palabras clave: innovación léxica, género, neologismo, artículo periodístico, blog

\footnotetext{
1 This study has been possible thanks to the funding of the program Becas de Doctorado en el Extranjero, BECAS CHILE, from the Comisión Nacional de Ciencia y Tecnología -CONICYT- from Chile's Government.

2 Universidad de Concepción, Concepción, Chile. pcanete@udec.cl
} 


\section{Introduction}

Many authors suggest that gender variable is one of the most important variable when it comes to the study of linguistic variation (Chambers, 2009; Cheshire, 2004; Moreno, 2009; Romaine, 2003; Serrano, 2008). In terms of language, Labov (1994) and Chambres (2009) affirm that women tend to be more conservative and use more standard forms than men, and that men are therefore considered to be more innovative than women. On another note, the use of new words shows the vitality of languages. We believe the study of these new lexical units, or neologisms, may allow for a better understanding of how the world changes and how speakers, both men and women, adapt to it.

It is these two perspectives which have inspired us to carry out this study (which is part of a more extensive $\mathrm{PhD}$ thesis). Our goal is to study the effect of the gender variable on lexical innovation. This study is two fold. First, we present an analytical review of Spanish press articles and blogs to determine whether men are actually more lexically innovative than women. That is, we want to know if men truly make more frequent use of neologisms. Second, if there are indeed differences, we explore whether or not men and women use different types of neologisms.

In what follows, we first present a review of the literature regarding studies of gender and language as well as of the concepts of neology and neologisms. Second, we set out the goals and hypothesis of this study. Subsequently, we describe the creation of our corpus and the methodology we followed. We then proceed to analyze and discuss the results and, finally, we set out our conclusions about this work.

\section{Literature Review}

\section{Gender}

In early sociolinguistic studies, gender was not considered a social variable and women were generally not included in this type of research. It is likely that this is due to the fact that researchers were mainly men who studied variation in language while considering variables only in terms of social status, age, and ethnicity. This early research focused mainly on pronunciation and grammar. The first study that had some effect on this area was by Peter Trudgill, a British sociolinguist. In 1974, he demonstrated that, regardless of social status, pronunciation of men from his hometown of Norwich was closer to the local vernacular than to standard English. He attributed this to overt and covert prestige, which we discuss later.

Subsequent to this work, the situation started to change under the influence of feminism and feminist linguistics. Lakoff (1975), a North-American linguist, reflected this shift in the book Language and Woman's Place. In her text, Lakoff introduced various ideas about language and women within the framework of sociolinguistics. Despite the fact that her ideas are currently considered somewhat obsolete, above all because of her emphasis on the powerlessness of female speakers is not in agreement with modern attitudes, her work was highly important, changing forever the course of sociolinguistic research (Coates, 2007).

In her article Gender, the British linguist Jennifer Coates (2007) reviews the history of gender studies. According to the author, in the 1980s, sociolinguists began paying closer attention to different aspects of language namely the conversational strategies of men and women. With this new focus, researchers found that many existent linguistic beliefs were false. For example, one of the notions that was dismissed was the fact that women are more talkative. This was debunked as researchers proved that in mixed groups men talked more than women.

In the early 1990s, the notion of gender as a social or cultural construction started to spread amongst sociolinguists and, since then, the fact that gender is constructed locally and that it interacts with ethnicity, social status, sexuality, and age has been emphasized. As mentioned, in early studies of gender, researchers did not distinguish between speakers' biological and cultural influences; therefore, social and linguistic behavior was primarily attributed to sex. However, this changed toward the end of the 20th century and many scholars now argue that, whether born as a man or woman, it is the social 
and cultural influences surrounding a speaker that determine her or his way of speaking (Coates, 2007). For this reason, it is very important to understand the difference between sex and gender.

Various authors agree with the fact that sex is a biological feature of speakers, whereas gender is a sociocultural aspect. Cheshire (2004) suggests that the term sex has been used to refer to the physiological distinction between men and women, while gender refers to the social and cultural elaboration of sexual differences, a process that restricts our social roles, opportunities and expectations. Chambers (2009) also suggests that distinguishing between sex and gender recognizes essentially biological and sociocultural differences, and he adds that differences in masculinity and femininity (that is, sex differences) begin to differ before birth, little after conception, while the sociology of masculinity and femininity-that is, gender differences-appear after birth. Romaine (1994) points out that she uses the term gender instead of sex to emphasize her interest in the sociocultural dimension of the division between men and women, rather than their biological features. Finally, Eckert (1989) gives us a more complete explanation regarding the fact that sex is not directly related to linguistic behavior, but rather reflects a complex social practice. According to Eckert, the correlation between sex and linguistic variables is merely a reflection of the effects of gender on linguistic behavior and that it is here where we ought to find explanations about such correlations. He also notes that "sociolinguists generally treat sex in terms of oppositional categories (male/female), and the effects of sex on variation are generally sought in linguistics differences between male and female speakers" (Eckert, 1989, p. 245). However, the effects of gender on linguistic behavior can appear in the existing differences between both groups (sexes). In this sense, sex is a biological category that is used as a fundamental base to differentiate roles, rules, and expectations in every society; hence, she concludes that the social construction of sex constitutes gender.

That being said, studies regarding gender and language have been carried out for decades. Trudgill (1974) was already suggesting that gender differences in language had emerged because gender, considered a social phenomenon, and is directly related to social behavior as men and women have different social roles and are expected to have different patterns of behavior. However, this (the different social roles) seems to be changing, which means that gender differences in language may change or even diminish. Regarding these differences, we will refer to important perspectives addressed in various studies that are related to assertions such as women are more conservative than men, women are more attached to the standard variable or covert prestige is stronger among men than among women (Cheshire, 2002). Here, we will first refer to standard language and then to the concepts of covert and overt prestige.

Various authors agree that women are more conservative than men and establish a relationship between women and standard speech. But what exactly do we understand by "standard" in this context? Cheshire (2004) suggests that standard and non-standard concepts tend to be considered as a given in social dialectology where standard forms correspond to those used with great frequency by the highest social class and also used quite frequently by all speakers when in formal contexts. The author also adds that these standard units are synonyms of overt-prestige units of the speech community.

Moreno (2009) affirms that the tendency towards a model of prestige is complemented by another reality: covert prestige has less influence on women than on men. This prestige is associated with uses that are not "highbrow." These forms of use are far from what is openly known as normative or adequate and are usually marks of "masculinity" among the lowest sociocultural stratum. Covert prestige, or group prestige, sits in opposition to overt prestige, which is a community prestige collectively associated with what is correct, adequate, or normative.

Moreno (2009) quotes Chambers and Trudgill to explain the tendency of women to follow models of prestige and suggests that, on the one hand, the lack of a prominent place in society creates the need of women to mark their social status through a specific behavior. On the other hand, the lack of connection of women in formal social networks 
makes them face formal situations more frequently. In other words, the positioning of men in social exchanges allows them to consider many situations to be hardly formal, while women consider these same situations as more formal in nature. Lastly, education tends to lead women to accomplish what is considered "their" social role by following rules of behavior considered socially acceptable.

Finally, we feel it is relevant to mention Romaine's (2003) suggestion that women are using the standard variable to reach the status they were denied. We could expect this need to diminish once women have more access to higher status and to better-paying jobs (Romaine, 2003).

\section{Lexical Innovation}

As mentioned above, our research focuses on lexical neology, or the lexical innovation of speakers. Specifically, we are interested in the effect that the gender variable may have on such lexical innovation. Boulanger (1988) writes that in the late 1970s and early 1980 s, the word neology could be defined in several different ways:

a) The process of creating new lexical units (general or terminological) by means of common linguistic creativity mechanisms found in a given language, whether consciously or unconsciously.

b) The theoretical and applied study of lexical innovation, either word formation methods (derivation, compounding, phrasing, etc.), meaning acquisition, recognition criteria, acceptability or spread of neologisms, relations between normalization or even social or socioprofessional inclusion of new lexis.

c) The institutional activity undertaken to organize, plan, and systematically collect, record, spread, and introduce lexical innovation within the framework of a specific linguistic policy.

d) The work of identifying the specialized sectors that require considerable lexical innovation to fill gaps in relevant vocabulary. All these activity spheres are, to varying extents, abundant producers of neologisms. e) The relation between novel words and dictionaries, especially the role of the dictionary as a filter for the recognition of neologisms and the analysis of the treatment of neology in dictionaries.

In this paper, we focus on lexical neology, that is, on the appearance of new words or lexical neologisms. Along the same lines, authors like Guilbert (1975) and Sablayrolles (2003) ${ }^{3}$ agree on the aforementioned definitions when suggesting that neology refers to, on one hand, the production of lexical units (either with the appearance of a new signifier or a new meaning for an existing word of the language) or, on the other hand, the linguistic component that studies the creation of these new units. Cabré (2002) provides a more complete definition taken from Rey (1988):

La neologia és una activitat, un procés, una dinàmica, que, a l'interior d'un sistema lingüístic, d'una entitat cultural o d'un grup social de parlants, produeix unitats lèxiques noves i unitats terminològiques noves, ja sigui per vehicular les novetats d'un món en evolució constant, ja sigui per designar conceptes que ja existien, per raons difícils de classificar i que poden estar lligades a fenòmens totalment subjectius i collectius com la necessitat d'expressar-se de manera nova o l'esnobisme de renovar l'inventari lèxic de la llengua. ${ }^{4}$ (p. 33)

\section{Conceptual Framework}

Our objective is to analyze lexical neologism. To this end, we will now define what we mean by neologism in the framework of this investigation.

As Deroy (1971) and Sauvageot (1971) suggest, the word neology appeared in the 18th century to designate a snobby attitude of expressing oneself and neology was defined as the art of innovation

\footnotetext{
3 Germán Gil (1993) and $M^{a}$ Pilar Ortega (2001) also agree with these authors on the definition of neology.

4 "Neology is an activity, a process, a dynamic that, inside of a linguistic system, a cultural entity or a social group of speakers, produces new lexical units and new terminological units, either to transmit novelties of a world constantly evolving, or to designate concepts that already existed, for reasons difficult to explain and that can be linked to the need of expressing in a new way or of the snobbery of renewing the lexicon of language" (Translation provided by the author).
} 
in response to the progress of ideas. After the Century of Lights, neology, stripped of its pejorative connotation, acquired its status as a linguistic term to designate innovation in language, a sense that it retains today.

Rey (1976) defined a neologism as "une unité du lexique, mot, lexie ou syntagme, dont la forme signifiante ou la relation signifiant-signifié, caractérisée par un fonctionnement effectif dans un modèle de communication déterminé, n'était pas réalisée au stade immédiatement antérieur du code de la langue". ${ }^{5}$ The author also affirmed that neologism was not a clear notion and that, for this reason, he qualified it as pseudoconcept, because it depends on a relative and subjective judgment of a feeling of novelty.

It is also important to take into account multidimensional criteria when studying neologisms. For this, authors such as Rey (1976) consider that a lexical unit is neological depending on its initial parameters of identification. Hence, he establishes the following three parameters:

- Temporary: all words that appeared in a recent period are considered neologisms

- Psycholinguistic: a neologism is a lexical unit that speakers perceive as new

- Lexicographical: a lexical unit can be considered neological if it is not documented in a specific lexicographical corpus.

In this investigation, we use the lexicographical criterion, an objective criterion that allows us to obtain a certain number of lexical units from the same corpus of exclusion. Regarding this matter, Boulanger (2010) indicates that, for the last 30 years, the identification of neologisms has relied on what is known as the corpus of exclusion. This is a specified set of dictionaries in which the neologism should not be present in order to acquire the new word label. Nevertheless, we also know that while being a relatively objective and practical criterion, this does have some limitations. Some words that

\footnotetext{
5 "Unit of lexicon, word, lexis or phrase, where the signifier form or the relation between signifier-signified, characterized by an effective functioning in a determined communication model, wasn't made by a stage immediately previous to the code of language" (Translation provided by the author)
}

are not documented in the reference corpus may not be new words at all; rather, they may be too old, too specialized, a type of word found only in a specific dialect, etc. However, we agree with Faura i Pujol's (1998) who writes that "la sistematicidad es la contrapartida positiva a las contradicciones que la elección de este criterio puede presentar" (p. 33) ${ }^{6}$, and with Freixa (2012) who points out that "este criterio es satisfactorio en la medida en que permite realizar un trabajo colectivo imparcial, sistemático y confiable" (p. 13). ${ }^{7}$

Finally, in our analysis we study whether the gender variable has an effect on lexical innovation. We observe differences not only in the number of neological units, but also in the type of neologisms. For this reason, we address this matter in our theoretical framework.

The Observatorio de Neología of the Universitat Pompeu Fabra provides a classification of the types of neologisms, which we adopt in our research. According to the Observatorio de Neología (Obneo, 2004), neologisms can be classified under the following categories: form, which include neologisms created by derivation (suffixation and prefixation); compounding (both learned and non-learned); lexicalization; syntactic conversion and phrasing; neologisms of meaning; loanwords (adapted and non-adapted); and some truncation mechanisms such as acronyms and shortening ${ }^{8}$.

\section{Methodology}

The general goal of this work is to study the effect of the gender variable on lexical innovation within the articles and blogs of three Spanish newspapers: $A B C$, El País, and La Vanguardia. To meet this goal, we perform a quantitative analysis to determine, on the one hand, if there is a difference

6 "Sistematicity is the compensation for all the contradictions that choosing this criterion can present" (Translation provided by the author).

7 "This criterion is satisfactory as it allows us to perform a systematic, reliable and impartial collective work" (Translation provided by the author).

8 We chose not to consider other labels that Observatorio uses for cases of difficult to classify words, cases of interference between prefixation and suffixation and cases of variation. 
in the number of neologisms used by women and men, and, on the other hand, if there is a correlation between the type of formation used in these lexical units and gender. Despite the fact that the existing literature still defends the perspective that women are linguistically more conservative and that men are more innovative, we hypothesize that the gender variable will not have a relevant effect on the lexical innovation of current Spanish press texts.

\section{Corpus}

Our corpus consisted of 116 press articles and 60 press blogs that were taken, in the first case, from three Spanish newspapers: $A B C, E l$ País and La Vanguardia, and, in the second case, from the online versions of these same newspapers. From each newspaper, we selected all articles from the Culture, Sport, Economy, and Opinion sections. For the blogs, however, we selected opinion and news blogs regarding the specific fields of breaking news, sports, technology, and culture, among others.

To control for the gender variable, we selected the same number of texts for each gender: from the 116 press articles, 56 were written by women and 60 by men, and from the 60 blog texts, 30 were written by women and 30 by men. All analyzed texts are recent with publication dates between January and September 2011. We carried out a manual count of terms to identify the neological units according to the lexicographical criteria cited above. If the neologism candidate was already registered in our corpus of exclusion (the Diccionario VOXUSO and the Diccionario de la Real Academia Española de la Lengua), we did not consider it as neological. Following this procedure, we obtained
109 neologisms in the newspaper articles and 102 neologisms in the blog texts. We then registered them in a database containing the following information: source publication, publication date, section (for newspapers), title, author, author's gender ( $M=$ male, $\mathrm{F}=$ female), word count, neologisms found and, finally, the percentage that these neologisms represent in relation to the total word count. This information is demonstrated in Table 1 below.

We registered the information from all texts stating whether several, one, or no neologisms were found. With this information, we carried out a quantitative analysis to obtain the number of neologisms used by women and men and to see which gender is more productive in terms of using new lexical units. Once the numerical values were obtained, we classified different neologisms according to their type in order to determine which mechanisms of word creation tended to be used by which gender. For this classification, we used the methodology proposed by the Observatorio de Neología of the Universitat Pompeu Fabra (2004) described above.

\section{Discussion of Findings}

This section is divided into three parts. In the first, we analyze the press articles; in the second, the blog texts; finally, in the third, we compare the results obtained in these two types of text. In both cases, we analyze the number of neologisms used by women and men to see which gender is more productive. Furthermore, we also analyze the specific kinds of neologisms used to see if there are differences between both genders in terms of the type of formation.

Table 1. Database

\begin{tabular}{|c|c|c|c|c|c|c|c|}
\hline Source & Date & Blog & Author & Gender & $\begin{array}{l}\text { Word } \\
\text { count }\end{array}$ & Neologisms & $\%$ \\
\hline $\mathrm{ABC}$ & 02-09-11 & $\begin{array}{c}\text { ¿Es seguro chivarse a } \\
\text { WikiLeaks? }\end{array}$ & AG & $\mathrm{F}$ & 354 & $\begin{array}{l}\text { - conspiranoia } \\
\text { - ciberunidad }\end{array}$ & 0.56 \\
\hline EP & 03-03-11 & Nación obesa & DA & $M$ & 710 & - telerrealidad & 0.14 \\
\hline LV & $22-01-11$ & $\begin{array}{l}\text { El misterio de las } \\
\text { banderas negras }\end{array}$ & FG & M & 821 & $\begin{array}{l}\text { - anticastrista } \\
\text { - cubanólogo }\end{array}$ & 0.24 \\
\hline
\end{tabular}




\section{Analysis of Press Articles}

Gender and number of neologisms. We analyzed a total of 116 articles and found a total of 109 neologisms the distribution of which is demonstrated in Table 2 below.

It is important to mention that to obtain the 60 articles written by men, we used one copy of each newspaper; however, to obtain the 56 articles written by women, we used four copies of $\mathrm{La}$ Vanguardia, three of El País, and three of $A B C$. Therefore, the first (superficial) conclusion is that men are more frequently represented as the authors of press articles than women. However, we must also consider that this gap could be attributed to our section selection since these sections may be marked by gender differences. We observed that the number of neologisms produced by women and men is almost the same in total and very similar within individual newspapers. Table 3 shows the number of neologisms that appear in the written articles by each gender.

If we take into account the length of the texts, we observe that the corpora are quite similar: the corpus of articles written by women contains 32,758 words and the corpus of articles written by men contains
27,563 words. If we establish a ratio between the word count and the number of neologisms in each corpus, we observe that, in the case of women, 1.6 out of 1,000 words are neologisms and, in the case of men, 1.9. As can be observed, the obtained results are similar.

We should mention that the number of neologisms is not evenly distributed throughout the articles; in some texts, we found up to seven neologisms, while in others we found none. To obtain more accurate results, we calculated, for each article, a percentage representing the total of neologisms in relation to the total word count. This yielded a percentage variation of between $0.07 \%$ and $1.36 \%$ between articles written by women and men respectively. The instance of $0.07 \%$ is unique as most of averaged around $0.13 \%$. These results indicate that men have a more innovative inclination, although the difference regarding the total for women is not highly noticeable.

\section{Gender and Types of Neologisms}

Data analysis revealed that there are no major differences between women and men in terms of the number of neologisms. Next, we set out to

Table 2. Total of neologisms by newspaper

\begin{tabular}{ccccc}
\hline Newspapers & Total of copies & Total of articles & Word count & Total of neologisms \\
\hline ABC & 4 & 23 & 9.766 & 20 \\
El País & 4 & 33 & 19.008 & 21 \\
La Vanguardia & 4 & 60 & 31.547 & 68 \\
Total & 12 & 116 & 60.321 & 109 \\
\hline
\end{tabular}

Table 3. Total of neologisms by gender

\begin{tabular}{ccccc}
\hline Newspapers & Women & $\%$ & Men & $\%$ \\
\hline ABC & 9 & 16.7 & 11 & 20 \\
El País & 10 & 18.5 & 11 & 20 \\
La Vanguardia & 35 & 64.8 & 33 & 60 \\
Total & 54 & 100 & 55 & 100
\end{tabular}

Table 4. Percentage of neologisms by gender

\begin{tabular}{cccc}
\hline & Word count & Total of neologisms & $\%$ \\
\hline Women & 32.758 & 54 & 0.16 \\
Men & 27.563 & 55 & 0.19
\end{tabular}


verify if there was any difference in the formation process of the neologisms used by each gender. The 109 neologisms obtained in the quantitative analysis correspond to token frequency. Once repetitions were removed, we obtained 107 units (type frequency), the quantity used to perform this analysis. In Appendix 1, these units are distributed into two groups, articles written by women and those written by men. In the following graph, we see different formation processes grouped by gender and some differences in the types of neologisms used by women and men ${ }^{9}$ :

We observe that the most common formation process is derivation, both in women and men, though the result is slightly higher among men. In this case, we find instances like antifundamentalista, buenista and preimplantacional. The use of loanwords is also similar between gender, with examples such as ebusiness, gauche-caviar, and high tech. However, there is an important difference in the use of compounding, since it is more frequent (over two times more frequent) in women's lexical innovation. Examples include atrapa-vídeos, estratégico-operativo and respuesta-consigna. In terms of truncation, only three neologisms were found and, as such, were left out of this analysis. These results show that neologisms created using language mechanisms are more frequent in both

9 As we have said, we removed repetitions to perform this analysis. genders. Therefore, there are no relevant differences between genders in this analysis.

\section{Analysis of Press Blogs}

We followed the same procedure for analyzing press blogs that we used in the analysis of press articles: On the one hand, we grouped the results by gender in terms of the number of neologisms used. On the other hand, we grouped the results by type of neologism, whether written by women or men (Cañete \& Freixa, 2015).

\section{Gender and Number of Neologisms}

As mentioned above, we analyzed a total of 60 blogs, 30 of which were written by women and 30 by men. All were published in the web pages of three Spanish newspapers: $A B C, E l$ País, and La Vanguardia. We analyzed these 60 blogs and found a total of 102 neologisms with the following distribution (see Table 5):

Table 5 shows that the $A B C$ newspaper contains more neologisms than the others, which really attracts our attention since it is considered the most politically conservative of the analyzed newspapers.

Table 6 shows how these 102 neologisms are distributed in the blogs written by women and men.

\section{Type of neologism}

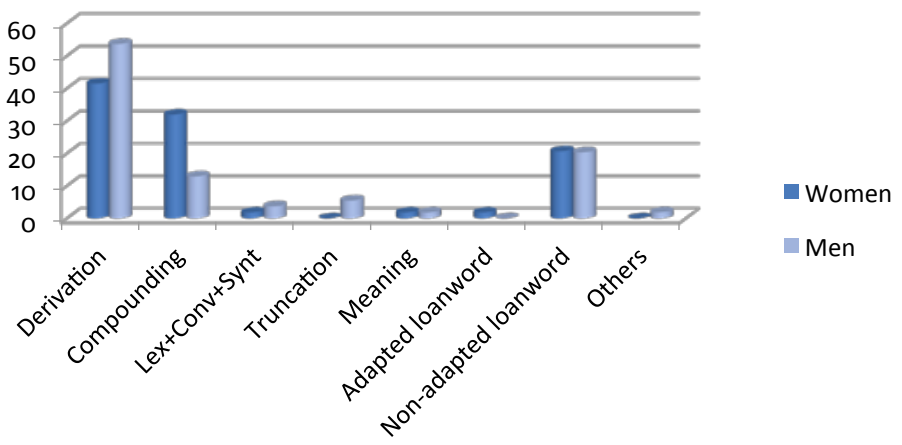

Graph 1. Results depending on the type of neologism 
Table 5. Total of neologisms by blog

\begin{tabular}{cccc}
\hline Blogs & Total of articles & Word count & $\begin{array}{c}\text { Total of } \\
\text { neologisms }\end{array}$ \\
\hline ABC & 20 & 9.118 & 41 \\
El País & 20 & 13.425 & 36 \\
La Vanguardia & 20 & 15.547 & 25 \\
Total & 60 & 38.090 & 102 \\
\hline
\end{tabular}

Table 6. Total of neologisms by gender

\begin{tabular}{ccccc}
\hline Blogs & Women & $\%$ & Men & $\%$ \\
\hline ABC & 24 & 35.8 & 17 & 48.6 \\
El País & 29 & 43.3 & 7 & 20 \\
La Vanguardia & 14 & 20.9 & 11 & 31.4 \\
Total & 67 & 100 & 35 & 100
\end{tabular}

These results were unexpected since we see that the number of women's neologisms almost doubles the number of those of men. Since women are considered more linguistically conservative than men, one might expect just the opposite to be true.

If we consider the length of the texts (a longer text may contain more neologisms), we observe that the corpora are very similar: the corpus of blogs written by women contains 19,885 words and the one written by men 18,205 . If we establish a ratio between the word count and the number of neologisms in each corpus, we observe that, in the case of women, 3.3 out of 1,000 words are neologisms and, in the case of men, 1.9 (see Table 7).

The results presented in Table 6 could describe different situations: it is possible that all women (or most of them) produce more neologisms than all men (or most of them). However, it is also possible that only a few of the analyzed individuals distort the results. Along these lines, we can state that the number of neologisms is not evenly distributed in blog texts, with some texts including up to 11 neologisms and others not containing a single one. To obtain a more accurate result, we took each blog and calculated the percentage of neologisms in relation to total word count. We then obtained a percentage variation of between $0.07 \%$ and $1.79 \%$ between the blogs written by women and men. This variability is similar in both genders. Therefore, the results obtained regarding the number of neologisms in these blogs seem to show that women are more innovative than men (see Table 7). We now propose, like we did for the newspapers, taking a closer look at the data in hopes of verifying whether women's and men's neologisms differ based on their formation mechanism.

\section{Gender and Types of Neologisms}

The 102 neologisms obtained in the quantitative analysis correspond to token frequency. Once repetitions were removed, we obtained 95 units (type frequency), the quantity used to perform this

Table 7. Percentage of neologisms by gender

\begin{tabular}{cccc}
\hline & Word count & Total of neologisms & $\%$ \\
\hline Women & 19.885 & 67 & 0.33 \\
Men & 18.205 & 35 & 0.19
\end{tabular}




\section{Type of neologism}

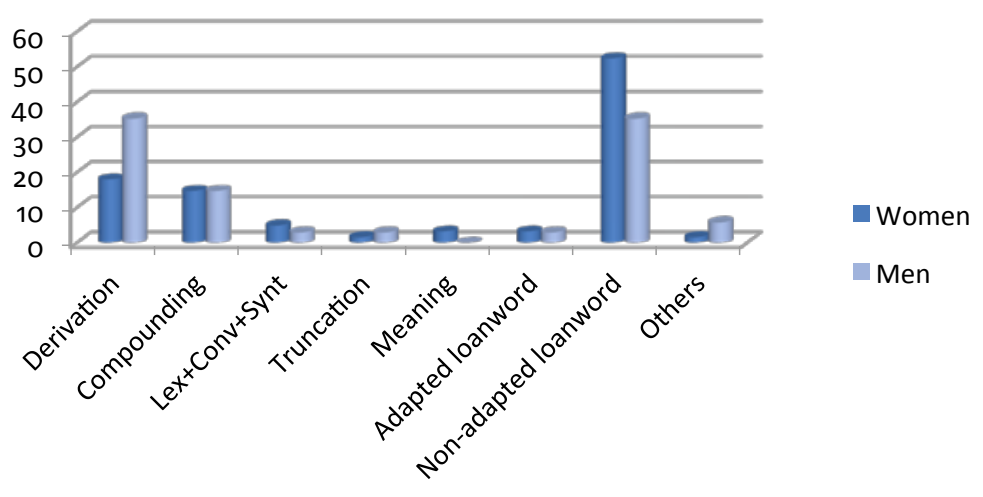

Graph 2. Results depending on the type of neologism

analysis. In Appendix 2, these units are distributed by those articles written by women and those written by men.

As mentioned in the press analysis, neologisms can be created via different mechanisms. We should therefore observe gender differences, if any exist, in the types of neologisms used. Graphic 2 shows the different formation processes used, grouped by gender.

Several trends became apparent in these results but only two of them stand out: derivation is two times more frequent in men's lexical innovation (examples include contraprogramar, posturismo and superordenador). Meanwhile, loanwords are more frequent in women's innovation processes, with examples including concept store, esteticien, and e-reader.

\section{Comparison between Press Articles and Blogs}

Regarding the number of neologisms, we observed that in 116 press articles, we found 109 neologisms and in 60 blogs we found 102 neologisms. In other words, we found more neologisms in blogs, probably because blog texts allow for more "freedom," as well as greater equality between women and men. It should also be mentioned that it is more difficult to find articles written by women in newspapers though, in blogs, women's texts are more common. This discrepancy could be attributed to the sections we selected (Culture, Sport, Opinion, and Economy).

In newspapers, we found more neologisms in La Vanguardia, than in El País and ABC, where we found almost the same number of units, as can be seen in Table 8 below.

Table 8. Total of neologisms per newspaper

\begin{tabular}{ccccc}
\hline & Newspapers & $\%$ & Blogs & $\%$ \\
\hline ABC & 20 & 18.3 & 41 & 40.2 \\
El País & 21 & 19.3 & 36 & 35.3 \\
La Vanguardia & 68 & 62.4 & 25 & 24.5 \\
Total & 109 & 100 & 102 & 100
\end{tabular}


We also see that the difference between the first and the other two newspapers is significant. However, in blogs, this difference is not significant; we found more neologisms in $A B C$ than in El País and La Vanguardia, where we found a slightly lower number of units. Therefore, we can state that the newspaper with the most neologisms of our sample group is La Vanguardia while the press blog with the most neologisms is $A B C$. The latter result was less predictable as $A B C$ is considered a conservative newspaper.

Nevertheless, if we analyze the number of neologisms in terms of gender, we observe that in newspapers the number of neologisms is similar between women and men (54 and 55 respectively), while in blogs, women use almost twice as many neologisms as men (67 and 35 respectively). This difference may be due to the type of texts or the editorial style of the newspapers. It is critical to underline the significant distinction between written press and blogs: Newspaper writers must comply with style criteria (Manual of Style) aiming to unify systems and forms of speech that provide a unique personality to the media and make reading easier for its accustomed public. In the case of blogs, the writer becomes their own editor and proofreader without having the pressure of the rules, besides the ones set by himself or herself. This broader freedom may explain the manifestation of a wider amount of neologisms in blogs than in newspapers. This behavior is more noticeable in women.

Regarding the grouping of the percentage of neologisms by gender, we observed that women use more neologisms in blogs than their female counterparts writing in newspapers by nearly a factor of two. Thus, in the case of women, 1.6 words out of 1,000 were neologisms in newspapers while 3.3 out of 1,000 was the figure in blogs. Meanwhile, among men, 1.9 words out of 1,000 were neologisms in both newspapers and blogs. Therefore, we conclude that men use the same number of neologisms in both texts, but that in newspapers men use more neologisms than women.

When the type of neologism is considered, we notice that in the newspaper format, the most common word formation process is derivation, followed by compounding and loanword use. Meanwhile, in blogs, the most common type is the loanword, followed by derivatives and compounds. In newspapers, similar tendencies for both women and men are observed: derivation is the most used process while the use of loanwords is similar. However, we noticed that the use of compounds is higher among women. In blogs, on the contrary, two significant tendencies stand out: derivation is two times more frequent in men's texts while loanwords are more frequent in women's texts. Therefore, we conclude that language mechanisms are more frequent in newspapers when we consider that derivation and compounding are more commonly used by women than loanwords. However, in blogs, the tendency is to use loanwords since both genders use this mechanism.

Finally, to sum up, several tendencies can be observed in newspapers and blogs.

In newspapers:

- We find more neologisms in La Vanguardia

- The number of neologisms used by women and men is similar

- We find less articles written by women

- Women use almost as many neologisms as men

- Language mechanisms are more frequent, especially derivation and compounding

In blogs:

- We find more neologisms (than in newspapers)

- There are more texts written by women in blogs than in newspapers

- Women use more neologisms, almost twice as many as in newspapers

- Women use twice as many neologisms as men

- Difference is observed when the type of neologism is considered: derivation is two times more common in men's texts while loanwords are more frequent in women's texts

\section{Conclusions}

The first difference observed is that there are more neologisms found in blogs than in newspapers. This may be attributed to the greater 
freedom that characterizes this type of text. We can also state that printed texts may be assumed to be more formal and conservative while electronic texts (and especially blogs) may be assumed to be more personal and have a format that allows more freedom when writing.

Another significant difference is the number of neologisms used when gender is taken into consideration. In our analysis of the newspapers, there were no significant differences regarding the use of neologisms between women and men. However, in blogs, the number of neologisms used by women was double that of men. This situation is quite surprising since it is in opposition to the common belief that women are more conservative and men are more innovative. Interestingly, women writing in blogs use twice as many neologisms as women writing for the print edition of newspapers. It is palpable that the freedom underlying blog writing has a significant influence over the neological behaviour of women.

Third, we are also interested in any differences in the type of neologisms used by each gender. We believe it is noteworthy that in blog texts, women use more loanwords, a more "transgressive" type of neologism than lexical units created with language mechanisms. This would seem to imply that women are more innovative than men. As for the formation process used to actually produce neologisms, our analysis demands that the next step in this investigation be the discursive and qualitative analysis of the units used by women and men. The goal will be to determine if the observed tendency is maintained or if different features become more apparent which may indicate a different tendency. This analysis will carefully detail each neological unit according to its formation process. For example, we may state that anticastrista, prodemocrático, hipercomunicar, and retuitear are words created using derivation. However, we might also say that the first two appear to be less neological than the second ones owing to grammatical and semantical reasons related to rules of word formation, although all four are units created using prefixation. The same happens with coaching and post which may seem less neological than loanwords like coolhunter or straw poll because they are much more frequent and have therefore settled in the language. Therefore, the formation process may provide interesting, new information in future investigation.

\section{References}

Boulanger, J.-C. (1988). L'évolution du concept de NEOLOGIE de la linguistique aux industries de la langue. In C. de Schaetzen (Ed.), Terminologie Diachronique. Actes du Colloque organisé à Bruxelles les 25 et 26 mars 1988 (pp. 193-211). Brussels: Centre de terminologie de Bruxelles. Institut Libre Marie Haps.

Boulanger, J.-C. (2010). Sur l'existence des concepts de "neologie" et de "neologisme." Propos sur un paradoxe lexical et historique. In M. T. Cabré, O. Domènech, R. Estopà, J. Freixa E M. Lorente (Eds.), Actes del I Congrès Internacional de Neologia de les Llengües Romàniques (pp. 31-72). Barcelona: Institut Universitari de Lingüística Aplicada, Universitat Pompeu Fabra.

Cabré. M. T. (2002). La neologia, avui: El naixement d'una disciplina. In M. T. Cabré, J. Freixa E E. Solé (Eds.), Lèxic i neología (pp. 29-41). Barcelona: Observatori de Neologia. Institut Universitari de Lingüística Aplicada, Universitat Pompeu Fabra.

Cañete, P. \& Freixa, J. (2015). Género e innovación léxica en blogs periodísticos españoles. In I. Alves E E. Simões (Eds.), Neologia das línguas românicas (pp. 1121-1140). São Paulo: CAPES, Humanitas.

Chambers, J. K. (2009). Sociolinguistic theory. Revised edition. Oxford: Wiley-Blackwell Publishing Ltd.

Cheshire, J. (2004). Sex and gender in variationist research. In J. K. Chambers, P. Trudgill, \& N. Schilling-Estes (Eds.), The handbook of language, variation, and Change (pp. 423-443). Oxford: Blackwell Publishing Ltd.

Coates, J. (2007). Gender. In C. Llamas, L. Mullany, \& P. Stockwell (Eds.), The Routledge companion to sociolinguistics (pp. 62-68). London: Routledge.

Deroy, L. (1971). Néologie et néologismes: Essai de typologie générale. La Banque des mots, 1, 5-12.

Eckert, P. (1989). The whole woman: Sex and gender differences in variation. Language Variation and Change, 1, 245-267.

Faura i Pujol, N. (1998). Futbol i llenguatge. La innovació léxica a les cròniques $i$ a les retransmissions futbolístiques. Barcelona: Publicacions de l'Abadia de Montserrat. 
Freixa, J. (2012). La néologie hispanique: Analyse d'une éclosion. Histoire Épistémologie Langage, 34(2), 9-28.

Gil, G. (1993). La motivación lingüística y la neología. Thesaurus, XLVIII, 3, 664-672.

Guilbert, L. (1975). La créativité lexicale. Paris: Larousse.

Labov, W. (1994). Principles of linguistic change. Oxford: Blackwell Publishers Ltd.

Lakoff, R. (1975/1995). El lenguaje y el lugar de la mujer (3 ed.). Barcelona: Hacer.

Moreno, F. (2009). Principios de sociolingüística y sociología del lenguaje (4th ed.). Barcelona: Ariel.

Observatorio de Neología. (2004). Metodología del trabajo en neología: Criterios, materiales y procesos. Barcelona: Institut Universitari de Lingüística Apliacada, Universitat Pompeu Fabra.

Ortega, M. P. (2001). Neología y prensa: un binomio eficaz. Espéculo. Revista de Estudios Literarios, Universidad Complutense de Madrid, 18. Retrieved from: http://www.ucm.es/info/especulo/numero18/ neologism.html [last visit: 15-03-2012]
Rey, A. (1976) Neologisme: Un pseudo-concept? Cahiers de lexicologie, 28, 3-17.

Romaine, S. (1994). Language in society. An introduction to sociolinguistics. Oxford: Oxford University Press.

Romaine, S. (2003). Variation in language and gender. In J. Holmes \& M. Meyerhoff (Eds.), The handbook of language and gender (pp. 98-118). Oxford: Blackwell Publishing Ltd.

Sablayrolles, J.-F. (2003). Linnovation lexicale. Paris: Honoré Champion.

Sauvageot, A. (1971). Valeur des néologismes. La banque des mots, 1, 29-36.

Serrano, M. J. (2008). El rol de la variable sexo o género en sociolingüística: ¿Diferencia, dominio o interacción? Boletín de Filología, XLIII, 175-192.

Trudgill, P. (1974). Sociolinguistics. An introduction to language and society (4th ed.). London: Penguin Books. 


\section{Appendix 1}

Neologisms documented in articles written by women and men.

\begin{tabular}{|c|c|c|}
\hline \multicolumn{3}{|c|}{ Neologisms documented in articles written by women } \\
\hline $\begin{array}{c}\text { amazing } \\
\text { atrapa-vídeos } \\
\text { autocomunicación } \\
\text { autoimponerse } \\
\text { autorreflexivo } \\
\text { berberófono } \\
\text { biopolítica } \\
\text { blaverismo } \\
\text { botiguer } \\
\text { buenismo } \\
\text { buenista } \\
\text { carnicería-copistería } \\
\text { cofundar } \\
\text { colegialización } \\
\text { comercializadora } \\
\text { concursal } \\
\text { downlight } \\
\text { ebusiness }\end{array}$ & $\begin{array}{c}\text { estratégico-operativo } \\
\text { eurozona } \\
\text { externalización } \\
\text { extremeño-alicantino } \\
\text { geoestratégico } \\
\text { halal } \\
\text { high tech } \\
\text { major } \\
\text { malismo } \\
\text { megaproyecto } \\
\text { microempresa } \\
\text { movies-on-demand } \\
\text { multiculturalidad } \\
\text { multilateralismo } \\
\text { nanomedicina } \\
\text { neoconservador } \\
\text { neurocientífico } \\
\text { outlet }\end{array}$ & $\begin{array}{c}\text { Pinganillo } \\
\text { pluridisciplinariedad } \\
\text { portátil } \\
\text { posapocalíptico } \\
\text { precuela } \\
\text { preimplantacional } \\
\text { recapitalización } \\
\text { recapitalizar } \\
\text { recolocar } \\
\text { recualificación } \\
\text { respuesta-consigna } \\
\text { spa } \\
\text { superglobal } \\
\text { toneladas-kilómetro } \\
\text { tripartit } \\
\text { unilateralismo } \\
\text { yihadista }\end{array}$ \\
\hline \multicolumn{3}{|c|}{ Neologisms documented in articles written by men } \\
\hline $\begin{array}{c}\text { antegreen } \\
\text { antifundamentalista } \\
\text { antimusulmán } \\
\text { aventis } \\
\text { banlieue } \\
\text { barcelonismo } \\
\text { blitzkrieg } \\
\text { café-restaurante } \\
\text { capitalizarse } \\
\text { cibercafé } \\
\text { cleptocracia } \\
\text { co-capital } \\
\text { copresidencia } \\
\text { desoccidentalización } \\
\text { diktat } \\
\text { espoir } \\
\text { esquiable } \\
\text { euromediterráneo }\end{array}$ & $\begin{array}{c}\text { franco-alemana } \\
\text { gauche-caviar } \\
\text { geoestratégico } \\
\text { gunners } \\
\text { hereu } \\
\text { local-global } \\
\text { londonism } \\
\text { londonismo } \\
\text { maragallismo } \\
\text { monsieur } \\
\text { pastueña } \\
\text { plus-que-parfait } \\
\text { porciolismo } \\
\text { poscolonial } \\
\text { post-Mubarak } \\
\text { preconcursal } \\
\text { pre-moderno } \\
\text { proleta }\end{array}$ & $\begin{array}{c}\text { proustiano } \\
\text { recapitalización } \\
\text { recapitalizarse } \\
\text { recepticio } \\
\text { semilibertad } \\
\text { sexa } \\
\text { sobrerrepresentación } \\
\text { superhéroe } \\
\text { supervivo } \\
\text { talonnette } \\
\text { traslacional } \\
\text { trasterrar } \\
\text { ultraortodoxo } \\
\text { valencianista } \\
\text { waka-waka } \\
\text { wikirrevolución } \\
\text { yihadismo } \\
\text { zapaterista }\end{array}$ \\
\hline
\end{tabular}




\section{Appendix 2}

Neologisms documented in blogs written by women and men.

\begin{tabular}{|c|c|c|}
\hline \multicolumn{3}{|c|}{ Neologisms documented in blogs written by women } \\
\hline $\begin{array}{c}\text { antiedad } \\
\text { arrondissement } \\
\text { autoexiliado } \\
\text { autoflagelarse } \\
\text { blog } \\
\text { blogger } \\
\text { bloguera } \\
\text { bloguero } \\
\text { botulínico } \\
\text { branché } \\
\text { chic parisien } \\
\text { chocolat } \\
\text { ciberunidad } \\
\text { clutch } \\
\text { coaching } \\
\text { concept store } \\
\text { conspiranoia } \\
\text { coolhunter } \\
\text { coupole } \\
\text { crowdfunding } \\
\text { cúpula-hangar } \\
\end{array}$ & $\begin{array}{c}\text { dictat } \\
\text { diseñador-inventor } \\
\text { e-reader } \\
\text { escaquear } \\
\text { esteticien } \\
\text { freak } \\
\text { glitter } \\
\text { hipercomunicar } \\
\text { hit } \\
\text { kir royale } \\
\text { making of } \\
\text { medicare } \\
\text { micro } \\
\text { microdonación } \\
\text { micropago } \\
\text { midseason } \\
\text { multi-función } \\
\text { nomenklatura } \\
\text { oversize } \\
\text { periodístico-intelectual } \\
\text { plumetti }\end{array}$ & $\begin{array}{c}\text { post } \\
\text { precuela } \\
\text { pro-democrático } \\
\text { reasignación } \\
\text { reexperimentar } \\
\text { sangüis } \\
\text { semi-seco } \\
\text { sitcom } \\
\text { spin-off } \\
\text { streaming } \\
\text { tableta } \\
\text { terremoto-tsunami } \\
\text { trending topic } \\
\text { tuit } \\
\text { tuitear } \\
\text { twitter } \\
\text { ultraportátil } \\
\text { welfare } \\
\text { whats ap }\end{array}$ \\
\hline \multicolumn{3}{|c|}{ Neologisms documented in blogs written by men } \\
\hline $\begin{array}{l}\text { anticastrista } \\
\text { blackberry } \\
\text { bliní } \\
\text { buenismo } \\
\text { bugre } \\
\text { chuchelo } \\
\text { contraprogramar } \\
\text { cubanólogo } \\
\text { espontaneismo } \\
\text { megápolis } \\
\text { meltdown } \\
\text { microblog } \\
\text { mollah } \\
\text { moral-emocional } \\
\text { old-school } \\
\text { palestinización } \\
\text { pimpampún } \\
\text { post } \\
\text { posturismo } \\
\text { proocidental } \\
\text { retuitear }\end{array}$ & $\begin{array}{c}\text { rinconete } \\
\text { sharía } \\
\text { sinómico } \\
\text { straw doll } \\
\text { supercélula } \\
\text { superordenador } \\
\text { supertormenta } \\
\text { telerrealidad } \\
\text { timeline } \\
\text { tuit } \\
\text { twitter } \\
\text { vice } \\
\text { zabiba }\end{array}$ & \\
\hline
\end{tabular}

